\title{
Do oceano dos clássicos aos mares dos impérios: transformações cartográficas do Atlântico sul
}

\author{
Carla Lois ${ }^{1}$ \\ João Carlos Garcia
}

RESUMO: $\bigcirc$ artigo explora as diferentes designações toponímicas que o espaço geográfico situado no Atlântico sul recebeu na cartografia européia dos séculos XVI e XVII. Nela, a representação do espaço continental era mais comum do que o registro dos espaços marítimos, frequentemente denominados por designações particulares - mares regionais -, atribuídas segundo a linha da costa. Uma série de conexões podem ser estabelecidas com o processo de consolidação do tráfico negreiro e a concorrência interimperial.

PALAVRAS-CHAVE: Toponímia. Atlântico sul. Mar Oceano. Mar Etiópico. Mar do Norte. Mar Ocidental.

ABSTRACT: This article explores the various place-names given to the geographic localities in the South Atlantic by European cartographers in the $16^{\text {th }}$ and $17^{\text {th }}$ centuries. Despite of the fact that representation of continental space seem to have been more common in mapmaking at the time than the depiction of oceans and seas, oceanic waters often received particular names regional seas - depending on the coastline in combination to the classical names. A series of connections can be established between this fact and the process of consolidation of slave trading and competition between empires.

KEYWORDS: Toponymy. South Atlantic. Ocean Sea. Ethiopian Sea. North Sea. West Sea.

As águas que hoje identificamos como o oceano Atlântico sofreram uma das transformações geográficas mais radicais da modernidade: desde os tempos clássicos tinham sido consideradas como um mar que circundava o conjunto das terras habitadas, genericamente conhecido como Mar Oceano; pelo século XV, a experiência da navegação europeia em direcção a oeste implicou uma nova percepção do que até então se imaginava como um vasto mar ${ }^{3}$. Dito
1. Docente da Universidad de Buenos Aires, Argentina E-mail: <carlalois054@gmail. com>.

2. Docente da Universidade do Porto, Portugal. E-mail: $<$ guadiana@portugalmail.pt>.

3. Entre os estudos mais recentes que abordam este te$\mathrm{ma}$, com preocupações geográficas e numa perspectiva próxima à do nosso texto, refeririamos: Matthew H. Edney (s.d.), Martin W. Lewis (1999), Elizabeth Mancke (1999) e Philip E. Steinberg (2001). 
4. Partimos de vários levantamentos internacionais de fontes cartográficas. Entre os luso-brasileiros, destacamos A. Cortesão e A. Teixeira da Mota (1960-1962), I. Adonias (1993) e J. C. Garcia (2001).

5. Cf. Ch. Jacob (1992, p. 263).

6. Ver H. Bresc (2003) de outro modo: ao contrário de outros espaços do globo que eram totalmente ignorados, o oceano Atlântico começou a configurar-se a partir da reinterpretação de um objeto que já havia sido imaginado, conceitualizado e, ainda que parcialmente, percorrido durante os séculos anteriores. Neste sentido, o desenho do novo oceano implicou uma ruptura profunda no que diz respeito aos conhecimentos herdados. Essa ruptura não implicou tanto o abandono de imagens anteriores, mas antes a adaptação da nova informação a esquemas prévios; e a expressão de novas redes de intercâmbio, que deram formas específicas às massas oceânicas.

Entre finais do século XV e inícios do XIX, no quadro das explorações marítimas ibéricas, circulou um amplo universo de imagens sobre o oceano Atlântico. Essas imagens dão conta de um espaço organizado em função de construções teóricas, historiográficas e científicas, ideológicas e geopolíticas, socioeconômicas, mas também da realidade prática.

Como, através dos mapas, abordar esses imaginários atlânticos? Tomando como ponto de partida um olhar sobre o extenso corpus de mapas manuscritos e impressos produzido no período em estudo, concentramos nossa atenção na análise sistemática das formas dos oceanos e nos topônimos inscritos em águas que hoje consideramos atlânticas ${ }^{4}$.

Um rastreio preliminar revelou que, segundo diferentes autores e segundo diferentes momentos históricos, os topônimos utilizados para designar as águas correspondentes ao atual oceano Atlântico tiveram um alcance variável. Partimos do princípio de que essas variações expressam não só um problema de designações mas também, e fundamentalmente, a indefinição dessa superfície, à qual o nome dava identidade. Consideramos que, devido à natureza do "objeto" que denominam, os topônimos oceânicos têm a característica de "irradiar metonimicamente sobre uma superfície" ${ }^{5}$ esse poder de identificação característico de todo o nome próprio; e daí concluímos que, do ponto de vista gráfico, existiram três tipos de estratégias que fizeram com que esses topônimos funcionassem como nomes genéricos para grandes extensões oceânicas.

Uma primeira identificação foi a presença de um único topônimo, dado que o oceano (ou o mar) não se ajustava exatamente à mesma lógica dos domínios terrestres e, por tal razão, não era passível de ser dividido segundo limites graficamente figurados ${ }^{6}$. Esse topônimo único podia estender-se sem considerar nem o tamanho nem a localização precisa do nome próprio. Uma segunda foi a localização central ou estratégica do topônimo, de tal maneira que o seu efeito de irradiação fosse visualmente expansível, sem contradizer outras informações inscritas sobre o mesmo mapa. Uma terceira foi a hierarquia do topônimo, particularmente determinada pelo corpo ou tamanho da letra. Neste sentido, o nome hierarquicamente superior funcionava como referência mais abrangente, podendo mesmo incluir vários outros topônimos. Estas estratégias não só não foram exclusivas, mas, antes, souberam combinar-se de maneiras diversas. E, mais ainda, outros topônimos mais "locais" multiplicaram as combinações possíveis.

Para desenvolver esta interpretação, organizamos o texto segundo 
etapas cronológicas, já que é possível reconhecer períodos em que primaram certas configurações e certos topônimos. Mas a periodização não responde apenas à comprovação quantitativa da ocorrência toponímica ou morfológica mas, antes, pretende ressituar as expressões cartográficas nos processos políiticos, econômicos e culturais em que foram produzidas, lidas, compreendidas e utilizadas.

aparecimento de um oceano no sul

Um oceano único e envolvente surge em muitas das representações do mundo que ilustram os manuscritos da Baixa ldade Média. Os livros de ciências e de navegação referem que esse mar oceano incluía todas as águas contíguas (fossem na superfície ou em profundidade) que envolviam o conjunto das massas terrestres7. Mas fica demonstrado, desde o início do século XVI, "que hay paso a nosotros a las antipodes [sic], contra la común opinión de filósofos", o que significava declarar "la ignorancia de la sabia antigüedad"8.

Não é difícil imaginar que a expansão europeia através da navegação atlântica implicou a redefinição das imagens que havia do mar. A experiência de percorrer novas rotas marítimas tinha de, necessariamente, influir na idéia que se fazia do conjunto oceânico. Tratou-se de um processo lento e conceitualmente confuso: a inércia daquele imaginário oceânico arrastou, de mapa em mapa, ithas e monstros que tinham habitado o mar oceano clássico?. Nos primeiros planisférios que incorporaram informações sobre o Novo Mundo, os cartógrafos decidiram não inscrever qualquer nome sobre essas águas, como é o caso de Contarini (1506), Ruysch (1507) ou Roselli (1 508); ou escrever Mare Oceanum / Mare Occeanus, como ocorre em Juan de la Cosa (1500), Cantino (1502) e Pesaro (1506); ou Oceano / Occeanus, como fazem Reisch (1504) e Lopo Homem (1519). Diríamos que, aparentemente, pouco parecia ter mudado no modo de imaginar a massa oceânica.

Essa mesma interpretação acerca da inércia que modelou o imaginário oceânico adquire mais força quando se analisam os mapas que não usaram nenhum topônimo para identificar as águas. Embora ao longo do século XVI surgissem outros nomes que, apesar de modo errático, tornaram-se mais frequentes, teremos de referir que Mar Oceano (ou simplesmente Oceano) se manteve e continuou a aparecer em muitos mapas e por muito tempo ${ }^{10}$. No planisfério de Ramuscio (1565) o vemos surgir como um termo genérico para todas as águas e, outras vezes, para designar vagamente territórios oceânicos longínquos ou desconhecidos, como no planisfério de Thorne (1527), na carta náutica de Porcacchi (1572), onde todas as águas situadas ao sul do Equador são denominadas Mare Oceano, ou na carta de André Thevet (1581), na qual se lê La Mer Oceane (Figura 1). O cartógrafo luso-malaio Manuel Godinho de Erédia,
7. Ver D. Cosgrove (2001)

8. Cf. López de Gómara (1552), fl. 5r-v).

9. Ver F. Lestringant (1989); e F. Péron (2005).

10. Cf. F. Relaño (2002, p. 127-129). 
隐 LE NOVVEAV MONDE DESCOVVERT ET ILLVSTRE DE NOSTRE TEMPS.

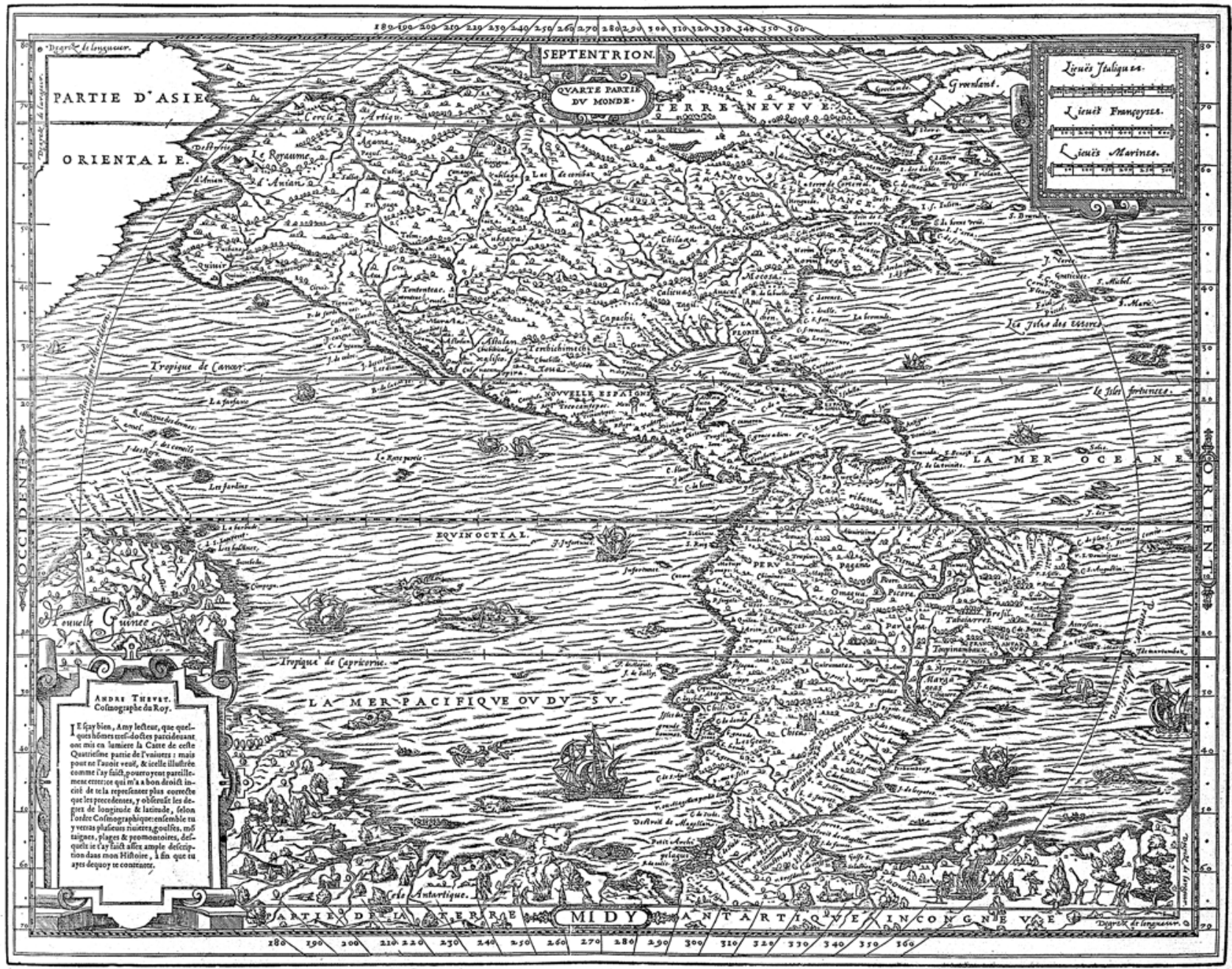

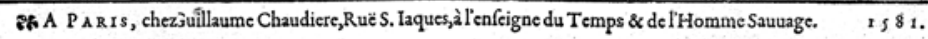

Figura 1 - "La Mer Oceane". André Thevet. Le Nouveau Monde Descovvert et Illustre de nostre Temps. 1581 . Instituto de Estudos Brasileiros / USP (acervo depositado temporariamente pela Justiça Federal), São Paulo.

11. Ver J. Gillis (2004)

no primeiro quartel do século XVII, ainda denominará assim o Atlântico sul; e J. B. Clovet, Gran Ocean, num mapa datado de 1780.

Por um lado, a ausência de topônimo pode significar ou desconhecimento ou que se tratava desse grande conjunto de águas que, desde o tempo de Aristóteles, era seguro envolver a ecúmena. Inclinamo-nos pela segunda hipótese, já que, então, a categoria "desconhecido" não tinha essa base empírica que se consolidou na modernidade. Trata-se, antes, de alguma coisa não vista, mas sobre a qual se podia ter conhecimento através dos livros ${ }^{11}$. Por outro lado, a ausência de topônimo dá seguimento a uma tendência anterior: não havia nome em muitas representações e mapas em que se referia o oceano. Por fim, o fato de sublinharmos 
a permanência do topônimo Mar Oceano não pretende chamar a atenção sobre o próprio nome e suas variantes, mas antes, e particularmente, fazer ressaltar a presença da carga semântica associada a Mar Oceano - quer dizer, à permanência das atribuições e dos valores relacionados ao oceano circular. $\mathrm{Na}$ primeira década do século XVI, o topônimo continuava a evocar essa natureza imensa e incontrolável ${ }^{12}$.

Mas, pela mesma altura, rapidamente Mare Occidentale tornou-se a expressão mais utilizada para designar as águas correspondentes ao atual Atlântico. Na década de 1510 se apresentava, até, como o nome mais recorrente, mantendo essa importância durante o meio século seguinte. No universo em análise, o topônimo Mare Occidentale surge pela primeira vez no mapa semioval, de estilo ptolomaico, publicado em Margarita Philosophica, em 1503'13. A explicação não é difícil: Mare Occidentale expressava uma das poucas certezas sobre essas águas - a de que se encontravam a ocidente da "nossa" localização, o que, em termos estritos, significava a ocidente da Europa.

Em El sitio y descripción de las Indias o Mundo Nuevo, sacada del libro de Cosmographia del S. leronymo Girava Tarragonez, editado conjuntamente com a Cosmografia de Pedro Apiano, em 1575, quando o autor descreve os limites do continente americano, refere-se a este Mar Ocidental, nos seguintes termos:

Y así tiene en todas las otras partes el Mar, el cual de la parte de Levante se llama el Océano Occidental, a causa que antes que esta tierra se descubriese se llamó siempre así. Y ahora se llama también del mismo nombre aunque a respeto de aquella tierra se habría de llamar Oriental; pero retenemos en esto, aunque impropiamente, el vocablo ya usado ${ }^{14}$.

No mapa manuscrito de Caverio, de 1505, na zona correspondente ao atual Atlântico norte, repete-se a expressão Oceanus Occidentalis. Ele é mesmo o único conjunto de águas que se distingue pelo seu nome, o que sugere uma singularidade que merece ser destacada ${ }^{15}$.

Mas, quando pesquisamos a denominação Mare Occidentale, comprovamos que esse topônimo sempre foi inscrito no hemisfério norte. É então que temos de reconsiderar se devemos procurar o Atlântico, tal como o conhecemos. Na realidade, os topônimos sugerem que, mais do que uma massa oceânica longitudinal, as primeiras configurações do Atlântico apareceram constituídas por dois mares ou oceanos, divididos pela linha do Equador. Se, livres do nosso olhar retrospectivo que procura um Atlântico longitudinal, voltarmos a observar o mapa de Thorne, de 1527, deveria chamar-nos a atenção a disposição transversal de uma grande massa oceânica.

De fato, a maior parte dos mapas que incluem o nome de Oceano Occidentale também identificam o Oceano Australis ou Meridionale lou alguma das suas variantes) ao sul do Equador, como se pode observar nas diversas edições do planisfério oval de Münster, de 1550-1578 (Figura 2), ou nos de Ruscelli (1561) (Figura 3), para mencionar imagens que tiveram grande circulação
12. Ver R. G. Peterson e outros (1996)

13. Ver F. Relaño (2003).

14. Cf. P. Apiano (1575, fl. XIIV).

15. Ver W. Randles (1989) 


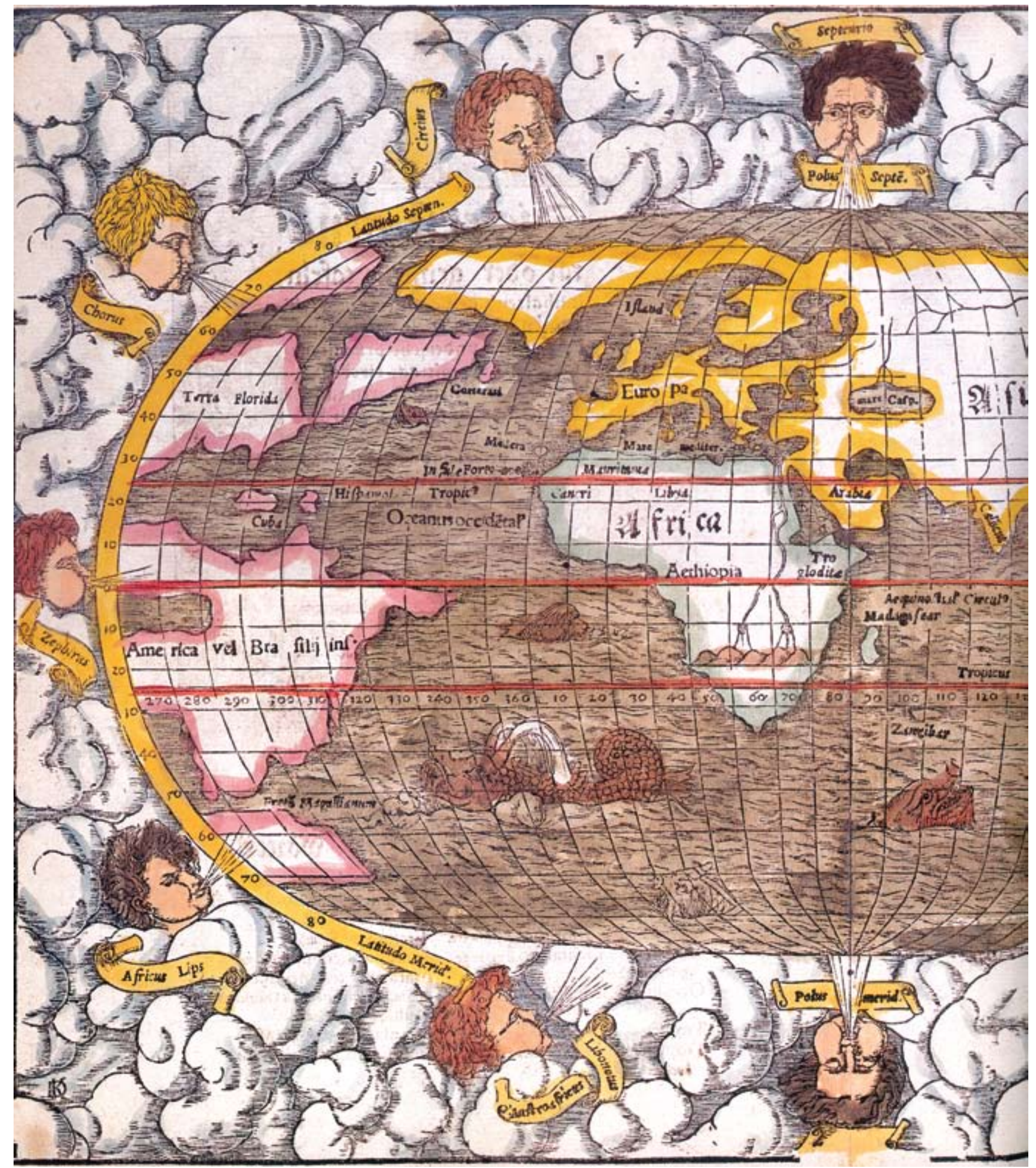

Figura 2 - "Oceanus Occidental". Detalhe do planisfério oval de Sebastien Münster. Das Earst General/Inhaltend die beschreibung. 1550-1578. Instituto de Estudos Brasileiros / USP (acervo depositado temporariamente pela Justiça Federal), São Paulo. 


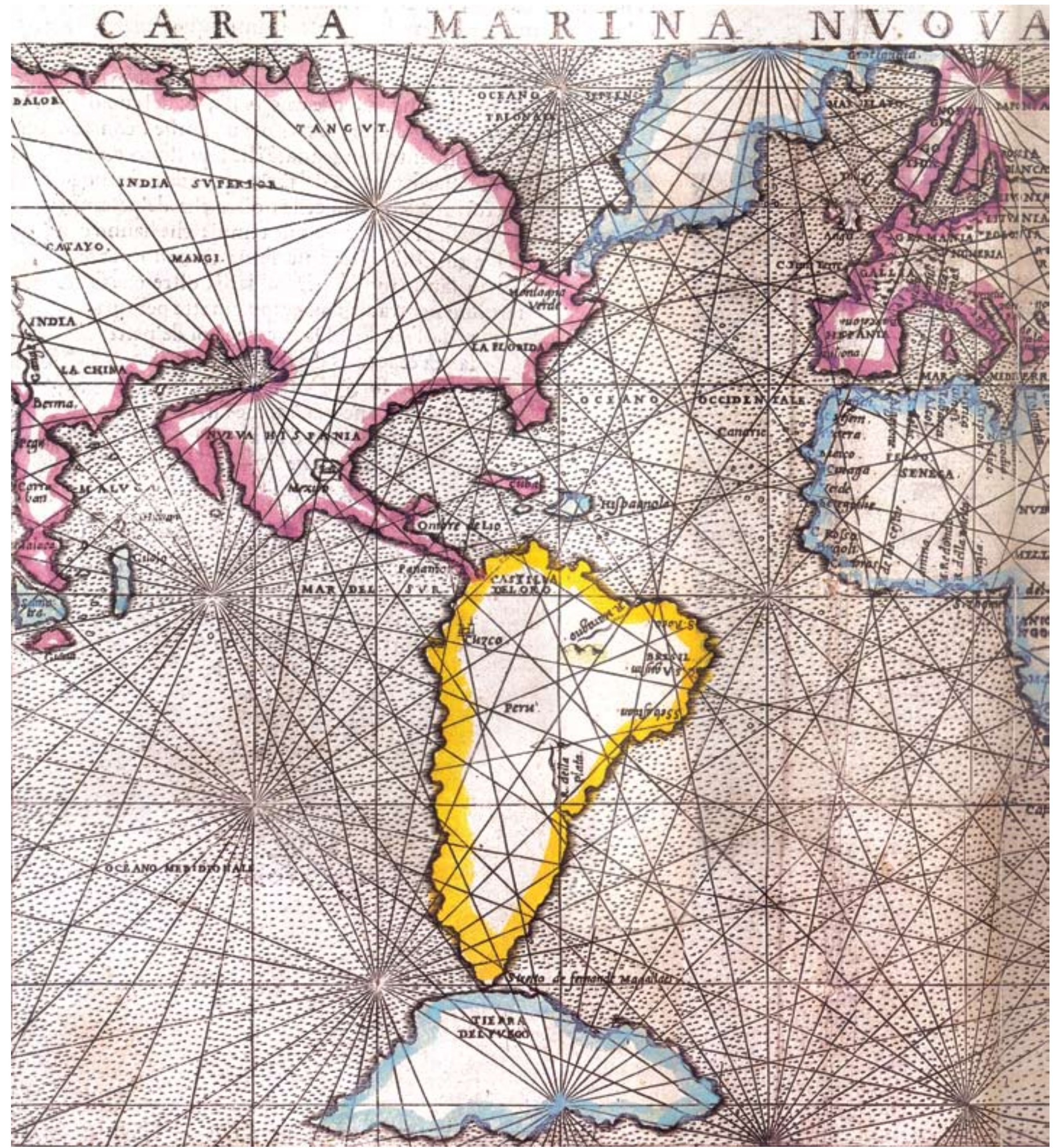

Figura 3 - "Oceano Occidentale" e "Oceano Meridionale". Detalhe do mapa de Girolamo Ruscelli. Carta Marina Nuova Tavola. 1561. Instituto de Estudos Brasileiros / USP (acervo depositado temporariamente pela Justiça Federall), São Paulo. 
16. Ver R. Pieper (2002); e C. Lois e J. C. Garcia (2007).

17. Ver A. Corbain e H. Richard (2004).

18. Cf. M. F. Alegria e outros (2007, p. 995-996). na Europa durante o século XVI; ou, ainda, nos mapas de Honter (156 1), Forlani (1565), Gasolfo (1565), Best (1578) e Lafreri (1580), entre outros.

Parece evidente que a natureza dos topônimos se relaciona com a posição das águas em relação ao continente europeu: o Oceano Ocidental, a oeste da Europa; e o Meridional, ao sul das terras conhecidas ${ }^{16}$. Tais posições implicam também configurações distintas: longitudinal para o primeiro; transversal para o segundo. E o Oceano Meridional não é apenas o contrapeso setentrional do Mar Ocidental, ele parece banhar litorais longínquos e desconhecidos. Talvez por essa razão está profusamente habitado por monstros e criaturas maravilhosas, como nos mapas de Belleforest (c. 1575), e nos de Apiano e de Girava $(1575)^{17}$.

Este modelo de oceano transversal - observável em grande parte dos planisférios impressos durante a primeira metade do século XVI - contrasta com o conjunto de planisférios manuscritos espanhóis elaborados na Casa de la Contratación, de Sevilha, mas também com os mapas portugueses e alguns italianos. Por um lado, não se inscrevia, nesses mapas, nenhum nome referente ao Oceano - como mostram Anon (1523), Turín e Vespucci (1524), Nuno Garcia (1525), Roselli, Agnese e Chaves (1548); ou usavam-se nomes genéricos, como mar, oceano, ou alguma combinação dos dois, como ocorre nos mapas de Juan de la Cosa, Cantino, Pesaro, Maggiolo, Rotz e Agnese. Por outro lado, esses mapas manuscritos apresentam um oceano longitudinal. Como veremos mais à frente, esse desenho longitudinal parece estar estreitamente ligado à experiencia atlântica das coroas ibéricas.

Enquanto o nome e a configuração do Oceanus Meridionalis revelam uma observação erudita desde o centro da Europa, o oceano que encontramos nas cartas ibéricas parece ser resultado de um olhar lançado a partir das rotas marítimas, do norte para o sul. No primeiro caso, o oceano é olhado e construído a partir da terra; no segundo, desde o mar. Entre 1500 e o início da década de 1520, para designar o atual Atlântico sul, concentram-se as denominações de Mar Oceano e Mar (ou Oceano) Meridional. Entre os mapas portugueses, ele surge pela primeira vez em três folhas do chamado Atlas Miller, de 1519 /de Lopo Homem e Reinéis); e, depois, no planisfério de Diogo Ribeiro, de $1529^{18}$. Será impresso no planisfério de Münster e Holbein, de 1532, a partir do qual se difunde entre um público mais amplo.

De uma forma geral, o termo "Mar", seja Oceano ou Meridional, desaparece de forma mais definitiva a partir dos anos de 1590. Contudo, convém referir que, enquanto, no sul, a denominação de Oceano se instala antes, no Norte continua em vigor aquela de mar do Norte, como encontramos nos mapas de Hondius (1597), Langenes (1598), Rosaccio (1 598), De Bry (1599) e outros. Nos mapas portugueses elaborados pela célebre família Homem (Lopo, Diogo e André), e para o período em estudo, Mare é uma parte do Oceano, mas é sempre um Mare Magnum: Mare Magnum Meridionale (1554 e 1558), Magnum Mare Meridionalis (1559, 1561 e 1568), Mare Magnum Australe (1561) e Magnum Mare Australe (c. 1565). 
De qualquer modo, durante o século XVI, certos oceanos recebem habitualmente nomes de mar: o oceano Pacífico surge como mar do Sul, em mapas de grande difusão, como os incluídos nas edições de Ortelius, do final da centúria. O mesmo acontece com o mar do Norte, no mapa de De Bry, de 1599, e com incontáveis exemplos por todo o século XVII. Já nos últimos anos do século XVIII, o Atlântico sul vai ser denominado Mer du Nort, por exemplo, nos mapas editados na França por De Lamarche e pela família Vagondy.

De mar Meridional a Oceanus Aethiopicus

A seção boreal do atual Atlântico, que só ocasionalmente fora denominada mar do Norte, passou a identificar-se, a partir da década de 1590, quase exclusivamente por esse termo, em particular nas imagens de Quad e Mercator. Antes, o topônimo mar do Norte só é encontrado nos mapas de Battista Ramusio, de 1534 e de 1556, e em outros três planisférios insertos em obras italianas, muito semelhantes entre si, da autoria de Gastaldi, de 1550 e de 1561, e de Camocio, de 1567.

O par Oceano Ocidental / Oceano Meridional, que tinha sido dominante deu lugar a uma nova dupla: mar do Norte / Oceano Etiópico. Não se pode esquecer que a expressão mar do Norte concilia-se com a de mar do Sul. Juntos parecem construir um outro par diferente, com base numa ligação específica que os une e relaciona-os como elementos de um mesmo sistema de referência, do qual, por oposição ao par anterior, não participam outros elementos (não existem os mares de Leste ou de Oeste).

O fato de que muitos mapas renascentistas parecem ter generalizado os nomes de mar do Norte, para todo o (atual) Atlântico, e mar do Sul para o (atual) Pacífico, obriga-nos a questionar se os contemporâneos não viam nesse conjunto alguma contradição - já que a configuração de ambos é longitudinal e não estão em eixo norte-sul um do outro - ou se, ao contrário, isso era aceitável, porque cada um desses topônimos remeteria para extensas massas de água que se estendiam de polo a polo, considerando um norte e um sul.

A aparente incongruência que se depreende do fato de dois oceanos longitudinais terem nomes como mar do Norte e mar do Sul - quando nenhum está ao norte ou ao sul de algum referente - tinha de estar associada a qualquer interpretação específica e diferente acerca dos próprios oceanos. Colocando o problema noutros termos, os dois topônimos tinham obrigatoriamente de referir-se a imagens, desses oceanos, diferentes das nossas atuais.

A experiência espanhola na Mesoamérica pode ter contribuído para dizer que um dos oceanos "está ao norte" e o outro "ao sul"; ou que, através da roła de navegação européia em direção oeste, se encontravam em ligação. No primeiro mar entrava-se pelo norte, no segundo, pelo sul. Esta última hipótese apoia-se no mapa inserto na primeira edição de Gómara, onde o Novo Mundo 
19. Ver J. Cortesão (2009) 20. Ver F. Mauro (1988). aparece "horizontalizado", e, embora não se inscrevam os nomes dos oceanos, recria-se essa orientação.

Um outro particular exemplo de estudo é o mapa de duplo hemisfério de Ramusio, de 1565. Sobre ele, enquanto todos os oceanos apresentam o nome genérico de Mare Oceano, é possível ler, junto à Nova Espanha, em letra mais pequena, o que sugere um menor nível hierárquico le por essa razão poderiam corresponder a parcelas do Mar Oceano), as seguintes denominações: mar do Norte, ao norte da Nova Espanha, o atual mar das Caraíbas; e mar do Sul, ao sul da Nova Espanha, no oceano Pacífico. No mapa de Ramusio, esse par de topônimos não parece duvidar em fazer atribuir a cada um deles apenas uma porção do Mar Oceano, concebida a partir do ponto de vista da Mesoamérica.

As primeiras importantes imagens cartográficas que incluem o Mare Aethiopicum, em torno da África Meridional, são os planisférios de Diogo Ribeiro, de 1529 (depositados nas bibliotecas de Weimar e do Vaticano). Depois, passa para as folhas dos atlas da família Homem (Diogo e André), entre os finais da década de 1550 e os finais da década seguinte. Isto significa que, em todo esse espaço do futuro Atlântico sul, o que conta é África, não a América do Sul. Ele é o oceano da África! É ao longo das suas costas que se desenvolvem as grandes rotas marítimas em direção ao Oriente, à Índia, à Insulíndia, à China e ao Japão. A importância do Brasil na geopolítica do colonialismo português demora a chegar: o primeiro atlas / roteiro detalhado do litoral brasileiro, atribuído a Luís Teixeira, datará de c. $1590^{19}$

Oceanus Aethiopicus é claramente um produto erudito, uma herança da cartografia da antiguidade. Por tal razão surge nas poucas cartas portuguesas impressas, como na de Duarte Lopes e de Pigafetta, de c. 1590, e na de Bartolomeu Lasso, inserta no itinerário de viagem de Linschoten, editado em 1596. Oceanus Aethiopicus - que no Theatrum Orbis Terrarum, de Ortelius, em 1570 (Figura 4), iniciara a sua versão impressa de grande impacto público - permanece nos mapas e, com certa regularidade, sobretudo nas folhas de atlas, de Mercator e Blaeu, a Jefferys (Figura 5) e Kitchin, passando por Visscher, De Wit, Van der Aa e Seutter, até meados do século XVIII. Depois, praticamente desaparece. $O$ boom de imagens com esta denominação inscrita, concentra-se, como referimos, entre os anos de 1580 e 1650, coincidindo, sintomaticamente, com o período de união das duas coroas ibéricas, durante o qual, o espaço colonial português no Atlântico sul é, em parte, ocupado pelos holandeses ${ }^{20}$.

Assim, pelo último quartel de Quinhentos, o Oceano Etiópico tornou-se mais recorrente, acabando por destronar o Mar Meridional ou Austral. Muito em consonância com a morfologia do atual Atlântico sul, teve tendência, mais do que o seu "antecessor", a ficar ligado à costa ocidental da África. Numa comparação com as denominações Meridional ou Austral, Etiópico apresentava uma conotação muito mais regional, pelo que não nos surpreende que, nos mapas analisados, a localização do topônimo tenha ficado restrita a áreas mais limitadas, junto aos litorais da África ocidental. 


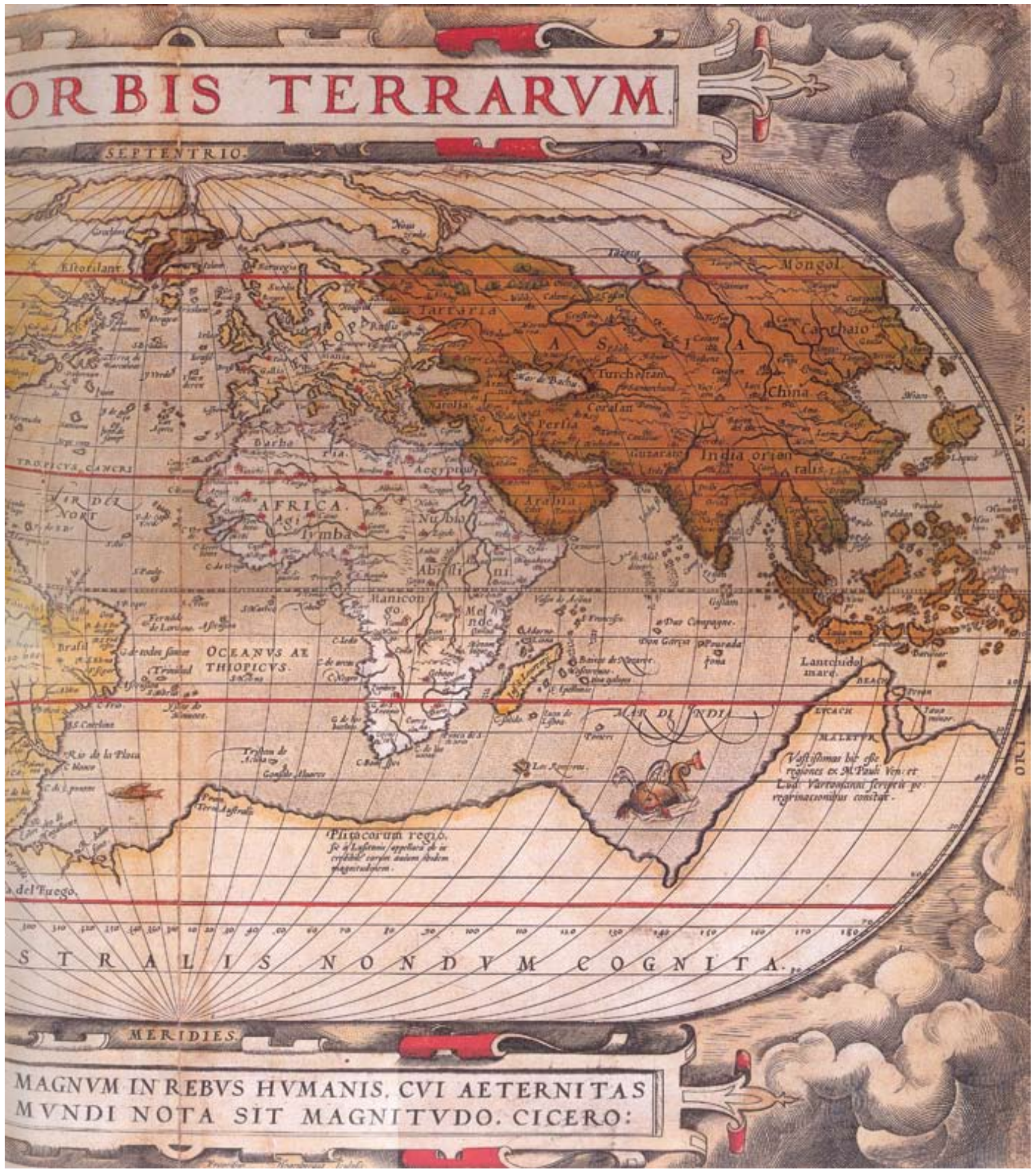

Figura 4 - "Oceanus Aethiopicus". Detalhe do mapa de Abraham Ortelius. Tipus Orbis Terrarum. 1570-1571. Instituto de Estudos Brasileiros / USP (acervo depositado temporariamente pela Justiça Federal), São Paulo.

Annals of Museu Paulista. v. 17. n.2. July - Dec. 2009. 


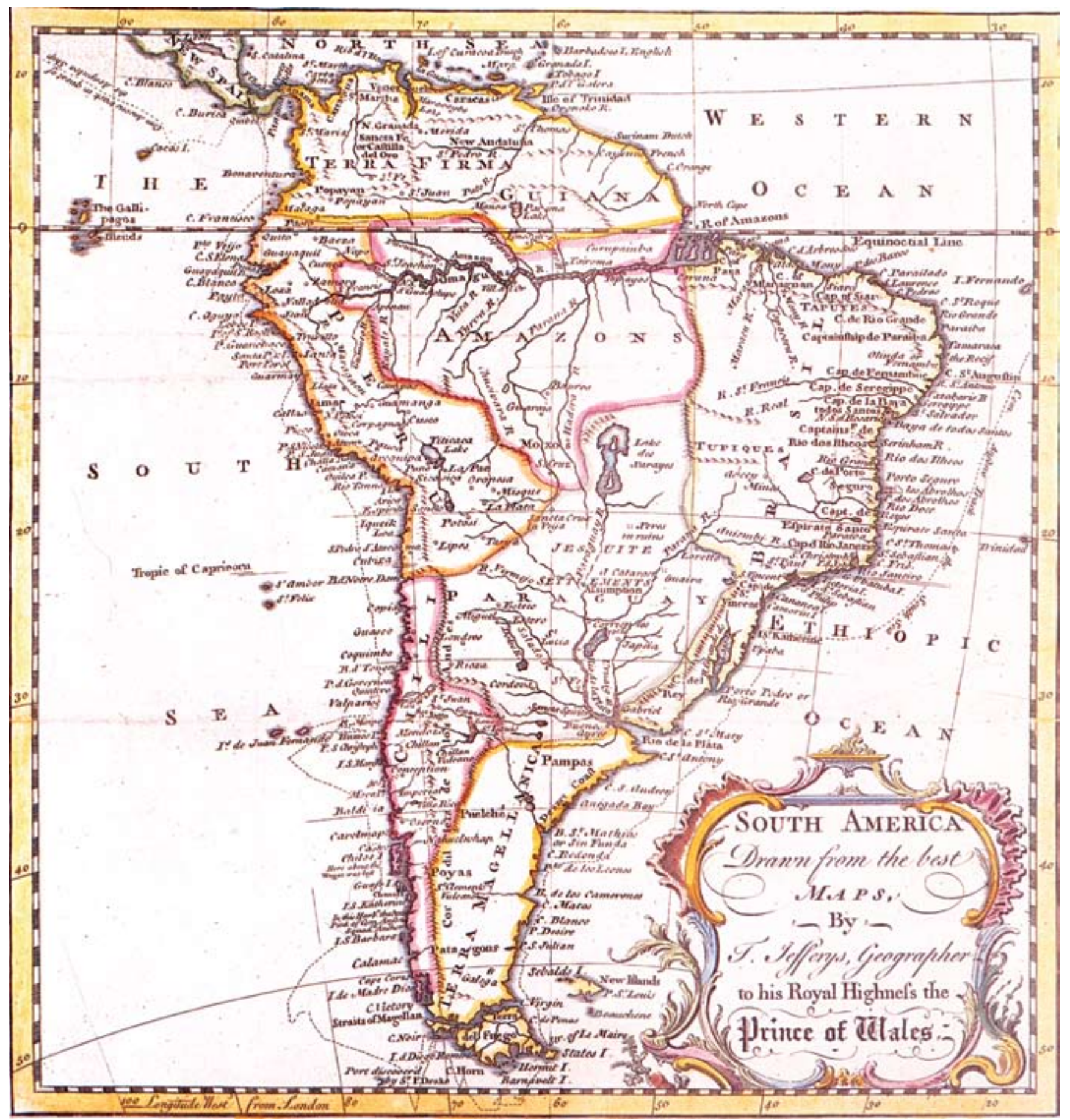

Figura 5 - "Ethiopic Ocean". Thomas Jefferys. South America Drawn from the Best Maps. 1749.Instituto de Estudos Brasileiros / USP (acervo depositado temporariamente pela Justiça Federal), São Paulo. 
O Mare Aethiopicum parece manter a sua conotação regional no mapa de Diogo Ribeiro, de 1529, frente ao Oceanus Occidentalis: o primeiro fica muito próximo da costa africana e a leste do Meridiano de Tordesilhas, enquanto o segundo, aparece a oeste, no território oceânico sob jurisdição castelhana. Os que referem "Oceano" são esmagadora maioria. Por um lado, a qualificação de "Oceano" parece ter alargado esse locus restrito e africano ao qual, em virtude da sua etimologia, a expressão Oceanus Aethiopicus parecia estar condenada, embora ao mesmo tempo o deixasse ancorado à África. Por outro lado, mesmo sendo certo que muitas vezes ficasse junto ao litoral africano, entre o Equador e o trópico de Capricórnio, como ocorre nos mapas de Diogo Homem, de 1558, e de André Homem, de 1559, a ausência de outros topônimos, e talvez o facto de sabermos hoje que se trata do Atlântico, torna possível fazê-lo extensível a todo o resto.

O fato de que aqueles topônimos mais gerais tenham sido substituídos por este, poderia ser um indício de que o Oceano Etiópico era pensado, fundamentalmente, como uma parte de um oceano maior, que poderia continuar a ser o Oceano Meridional. Não deixa de ser notório que, salvo escassas exceções, Aethiopicus foi, na maior parte das vezes, denominado "oceano", enquanto que o seu par Norte, sempre foi um "mar". A versão de Mare Aethiopicum não volta a aparecer. Mas, durante o último terço do século XVI, Oceanus Aethiopicus repete-se em muitos mapas e atlas, como complemento austral do mar do Norte. Assim acontece nos mapas de Ortelius, Belleforest, Petri, Aniana, Andreas, Porro, Balgrave ou Mercator; há mapas que, em lugar de referir "Oceano", divulgam Mare Aethiopicum, como, por exemplo, os de Ribeiro, de 1529, ou de Heyns, de 1577.

Finalmente, o fato de que o binômio Oceano Occidentale / Oceano Meridionale tenha sido substituído por Mar del Norte / Oceanus Aethiopicus, e, mais especificamente, de que o primeiro par de expressões (e não apenas um dos seus componentes) tenha sido substituído em bloco por um novo par, pode sugerir que, pelo final dos Quinhentos, apesar da diferenciação toponímica, as duas massas de água começavam a formar um só conjunto.

A configuração do oceano Atlântico moderno

O mapa cordiforme de Oronce Finé, de 1534, é a imagem onde, talvez, mais precocemente a disposição do topônimo "Atlântico" parece corresponder a um elemento marítimo semelhante ao atual oceano Atlântico. Aí se distinguem três massas oceânicas: Oceanus Atlanticus, Oceanus Magellanicus e Oceanus Indicus, que se observam como três grandes bacias de limites mais ou menos definidos. A localização, no hemisfério norte, do termo "Atlântico" Imas sem relação com a cadeia montanhosa que a sua etimologia justifica) e o tamanho da letra com que ele é inscrito, semelhante ao utilizado para os outros oceanos, 
21. Ver F. Braudel (1992).

22. Cf. A. Ronconi (1931, p. 312).

23. Ver L. Pérez Vilatela (1995). fazem-nos crer que se trata de um topônimo genérico para designar o que mais tarde será o oceano Atlântico ${ }^{21}$. Durante o século XVI, como termo genérico, a expressão Oceanus Atlanticus surge, ainda, no mapa de Gilbert, de 1576.

Será importante esclarecer o uso do termo Atlântico como genérico porque, na realidade, não era um topônimo novo, provinha de uma larga tradição. Segundo o detalhado estudo de Ronconi, Atlântico aparece na literatura clássica para designar apenas "golfo" - como na Ora Marítima, de Avieno, o famoso poema do século IV - e ainda que fontes anteriores - como a descrição de Dionysius Periegetes do mundo então habitado - refiram um Sinus Atlanticus, a geografia antiga sempre identificou o Atlântico nesse sentido restrito que, depois, foi alargando progressivamente o seu significado22. Em sua obra mais conhecida, escrita em grego, (c. 120 d.C.), Periegetes descreve a ecúmena seguindo Aristóteles e outras fontes gregas: o Mundo era uma superfície plana, flutuante, rodeada por um oceano. Supõe-se que Heródoto foi o primeiro a ampliar, ainda que com imprecisão, o uso do topônimo Atlântico ao Oceano Ocidental.

Essa aura erudita que tinha por fontes as raízes clássicas ligava-se, em boa parte, tanto com o perfil de cartógrafos e de gravadores que escolhiam o topônimo, como com o tipo de mapas em que ele estava presente. Por exemplo, "Atlântico" foi incluído em várias imagens cartográficas ptolomaicas que mostravam apenas o Velho Mundo, como o mapa semioval inserto em Margarita Philosophica, publicado por Gregor Reisch, em 1503, onde se pode ler Mare Occidentale e Athlanticum. Aí, o termo Atlântico, indicava claramente, para os vindos do Mediterrâneo, as águas que banhavam os litorais situados para além dos montes Atlas ${ }^{23}$.

Mas o topônimo Atlântico reaparece também em certos mapas modernos que iá incorporam o Novo Mundo: o Mare Atlanticum surge igualmente em Münster (1540) (Figura 6) e no mapa duplo-cordiforme de Oronce Finé (1531). Esses, não só mantêm a localização africana do topônimo como também o deixam fixado no hemisfério norte. Como referimos, se considerarmos que as águas tomavam os nomes das terras adjacentes, esses mares eram, muito particularmente, mares africanos. De fato, no mesmo local onde costuma aparecer o termo Atlântico, o mapa de Apiano, de 1520, refere Sinus Magn[us] Affr[icae].

Em principio, a primeira utilização do termo Atlântico para designar as águas que estavam para além do alcance local previsto pela etimologia ocorreu no mapa de Joachim von Watt (Vadianus), de 1534, onde Atlântico é apresentado como sinônimo de Oceanus Occidentales. Embora siga ancorado no hemisfério boreal, parece expandir-se para águas que não eram só africanas. Nesses primeiros movimentos, a dilatação do Mare Athlanticum tendia a fazê-lo fundir-se com o Mare Occidentale.

A origem eminentemente parcial e local do topônimo reaparece quando se comparam mapas de diferentes escalas. Uma das edições renascentistas do clássico Solino, de 1538, torna explícito o referente terrestre deste topônimo: no interior do continente africano, quase vazio, figuram-se e nomeiam-se os Mons Atlas. Muito mais tarde, no atlas de Abraham Ortelius, de 1570, algumas folhas 


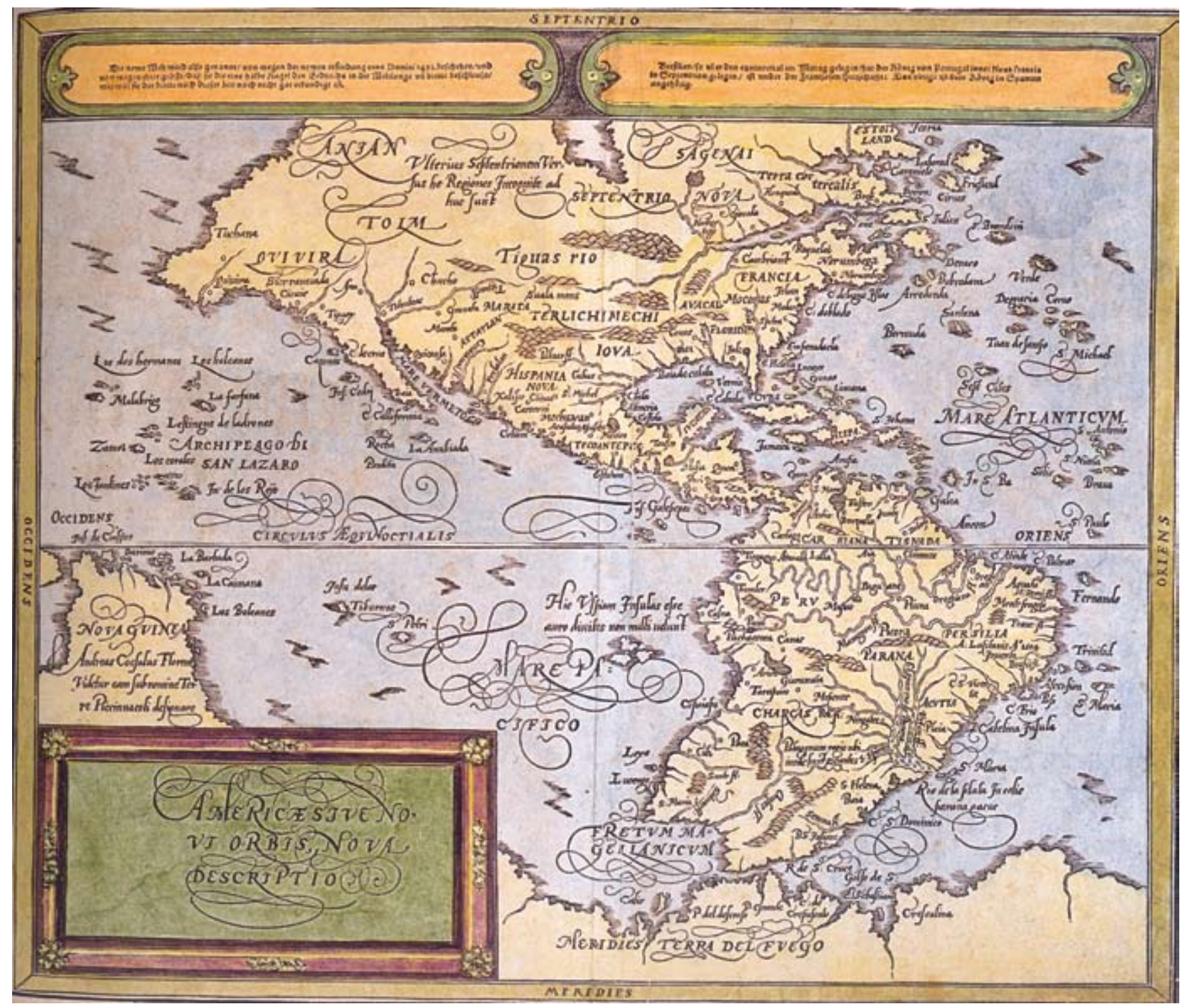

Figura 6 - "Mare Atlanticum". Sebastien Münster. America Sive Orbis Nova Descriptio. 1540. Instituto de Estudos Brasileiros / USP (acervo depositado temporariamente pela Justiça Federall), São Paulo.

relativas à Africa reconhecem o Mare Atlanticum ou Oceanus Atlanticus. Mas nas 24. Ver Ch. Boxer (1992). folhas em que se apresenta o mundo em seu conjunto, ou o continente americano, sobrevivem as referências ao Mar Ocidental.

Enquanto que nos mapas do Mundo persiste uma idéia "ecumênica", nas folhas parciais consagra-se esta "perspectiva africana", tributária tanto do conhecimento clássico herdado relativo à "terceira parte" lo que, no Renascimento, constituiu-se como África), e a prática tradicional de batizar as águas segundo os territórios adjacentes unida ao interesse renovado sobre essa parte, coincidindo com a intensificação do fluxo das viagens marítimas entre Portugal e a Índia, ao longo das costas africanas ${ }^{24}$. Como veremos, de um ponto de vista estritamente

Annals of Museu Paulista. v. 17. n.2. July - Dec. 2009. 
25. Ver M. L. Martín-Merás (2003). toponímico, no hemisfério sul, o "Atlântico" só aparecerá de modo mais concreto quando, na primeira década do século XVIII, desaparecer, lentamente, o Oceanus Aethiopicus. A maioria das imagens em que isso ocorre são de mapas ingleses, como os editados por: Herman Moll, na versão de Atlantick Ocean, em 1709; E. Bowen, localizando o Atlantic Ocean junto à costa argentina, em 1747 e 1752; e Th. Jefferys, em 1780 ou John Luffman, em 1801.

\section{A América e o Atlântico nos mapas ibéricos}

Se observarmos os mapas ibéricos dos séculos XV e XVI, uma de suas características mais originais é a aparição e consolidação do oceano Atlântico como espaço único e monolíitico, enquanto a entidade da quarta pars começa a recortar-se lentamente num novo mapa-múndi, e começam a tomar corpo as duas grandes massas de água que a rodeiam.

Quando nos referimos aos "mapas ibéricos" não estamos aludindo apenas à origem peninsular dos autores dessas imagens. Com a expressão, queremos designar um universo cartográfico de documentos estratégicos, concebido pelos Estados que encabeçavam a expansão europeia transoceânica. Os mapas dos cartógrafos da Casa de la Contratación, de Sevilha, e do Armazém da Guiné e Índia, de Lisboa - tanto do ponto de vista da produção institucional, como das concepções que deram sentido à massa continental americana -, constituem uma alargada família ${ }^{25}$.

Assim, essa aparição do Novo Mundo e essa configuração do Atlântico nos mapas ibéricos não parecem um acaso: foi o desenvolvimento longitudinal da América, quase de polo a polo, o que começou a recortar a individualidade do Atlântico moderno e a fechar os seus limites. Por tal razão, não surpreende que essa configuração tenha funcionado como um padrão, repetido por todos os mapas ibéricos manuscritos. $E$, o que não parece ser uma coincidência fortuita, entre os poucos mapas impressos que divulgaram essa forma, destaca-se o célebre mapa-múndi de Martin Waldsemüller, que foi profundamente inovador neste e em muitos outros aspectos, como o da própria e definitiva denominação do continente, ligada à figura de Vespúcio.

Ainda que a disposição longitudinal da América vá contribuir para dar homogeneidade às águas do Atlântico moderno, só muito excepcionalmente o continente americano foi o referente terrestre para designar o oceano: apenas o mapa de Michele Tramezzino, de 1554, refere Mare Americum; e o de Christian Sgrooten, de 1588, Oceanus Novae Indie Occidentalis. $O$ fato pode ser atribuido à confusão existente sobre a natureza do Novo Mundo. Em alguns mapas portugueses, encontramos Mare Antilarum, como no de Lopo Homen, de 1554, ou no de Diogo Homen, de 1558.

Esse Atlântico era território de disputas sobre a repartição dos domínios portugueses e espanhóis, era o terreno sobre o qual deveria materializar-se a linha 
de Tordesilhas. Mais do que as experiências empíricas, o certo era tratar-se de uma linha puramente especulativa, daí sua presença na Cartografia ibérica. De fato, o meridiano de Tordesilhas apareceu em muitos dos mapas espanhóis e portugueses do início de Quinhentos, o que pode interpretar-se como uma clara intenção de fixar uma posição diplomática. Não pode ser só o acaso a explicar que os mapas não ibéricos tenham omitido sempre essa fronteira, mesmo quando usaram fontes cartográficas que a tinham inscrita. No mapa de Diogo Ribeiro, de 1529, encontramos o meridiano com grande protagonismo gráfico, já que na segunda parte do título se refere claramente: "La Qual [carta cosmográfica] se devide en dos partes conforme a la capitulación que hicieron los Catholicos Reyes de España e el Rey Don Juan de Portogual en Tordesillas An[n]o de [1494]".

É certo que esta unidade geográfica do Atlântico poderia parecer dividida por Tordesilhas, mas, na realidade, não fazia mais do que reafirmar o caráter longitudinal das águas atlânticas. Embora pareça, em alguns casos, ter servido para atribuir o "mar africano" aos portugueses, em estreita sintonia com os domínios coloniais, queremos reforçar a ideia de que essa linha não separava dois oceanos distintos, mas servia, sim, para dividir soberanias marítimas. E o que podemos observar no mapa de Diogo Ribeiro, de 1529, onde a linha meridiana, a oeste das Canárias, separa o Mare Ethiopicum (a leste) do Occianus Occidentalis (a oeste).

Desde a segunda metade do século XVI, os mapas portugueses, que desde muito cedo tinham configurado um Atlântico longitudinal, ensaiam subdivisões do Atlântico sul. Essa repartição segue uma lógica geométrica: as linhas que a estruturam são o Equador, o trópico de Capricórnio e o círculo polar. Em alguns mapas inscreve-se, no meio do oceano, uma escala de latitudes sobre um meridiano equidistante da África e da América do Sul. Assim, encontramos o espaço oceânico dividido em quatro partes: Mare Brasilis (em cima, à esquerda), Mare Argenteum (em baixo, à esquerda), Mare Aethiopicum (em cima, à direita), Mare Bona Espei (em baixo, à direita).

No século XVII, a subdivisão do Atlântico sul recupera a toponímia sul-americana e surgem, assim, três mares: do Brasil, do Paraguai e de Magalhães, tendo este Sanson como fonte. Tal subdivisão aparece em mapas holandeses e, depois, franceses e italianos; e, ainda, como partes do Oceano Etiópico ou do mar do Norte. O século XVIII dará continuidade a essas subdivisões, observáveis nas produções das várias escolas nacionais de cartografia, desde os mapas de Mortier, de Van der Aa, ou de Seutter, aos de De Fer ou dos Vagondy. A alternativa para Mer de Paraguay é Mer de La Plata, por exemplo, difundido por Nicolas de Fer, em 1717 (Figura 7). Junto aos litorais africanos permanece o Mar do Congo, presente nos mapas de Van der Aa (1715) e De Fer (1717), por exemplo, numa herança recebida de Coronelli (1691) (Figura 8), e fixa-se mais para sul, substituindo, nas obras dos mesmos autores, o Mar da Boa Esperança e o Mar dos Cafres.

Em mapas de escalas maiores, como são os referentes aos continentes africano ou sul-americano, as subdivisões mostram maior variedade de mares. Em 


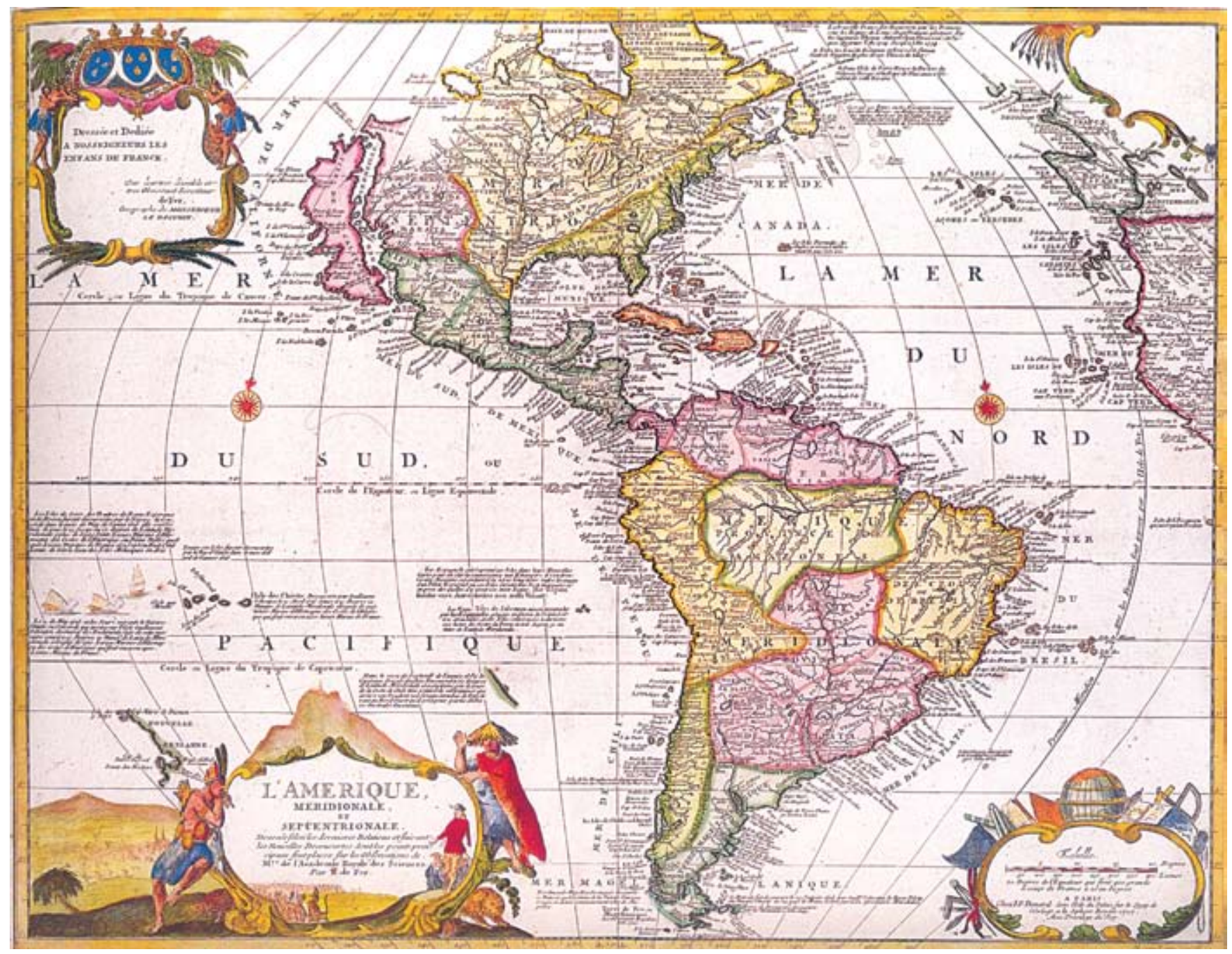

Figura 7 - "Mer du Bresil/ Mer de La Plata". Nicolas de Fer. L'Amerique Meridionale et Septentrionale.... 1717. Instituto de Estudos Brasileiros / USP (acervo depositado temporariamente pela Justiça Federal), São Paulo. 


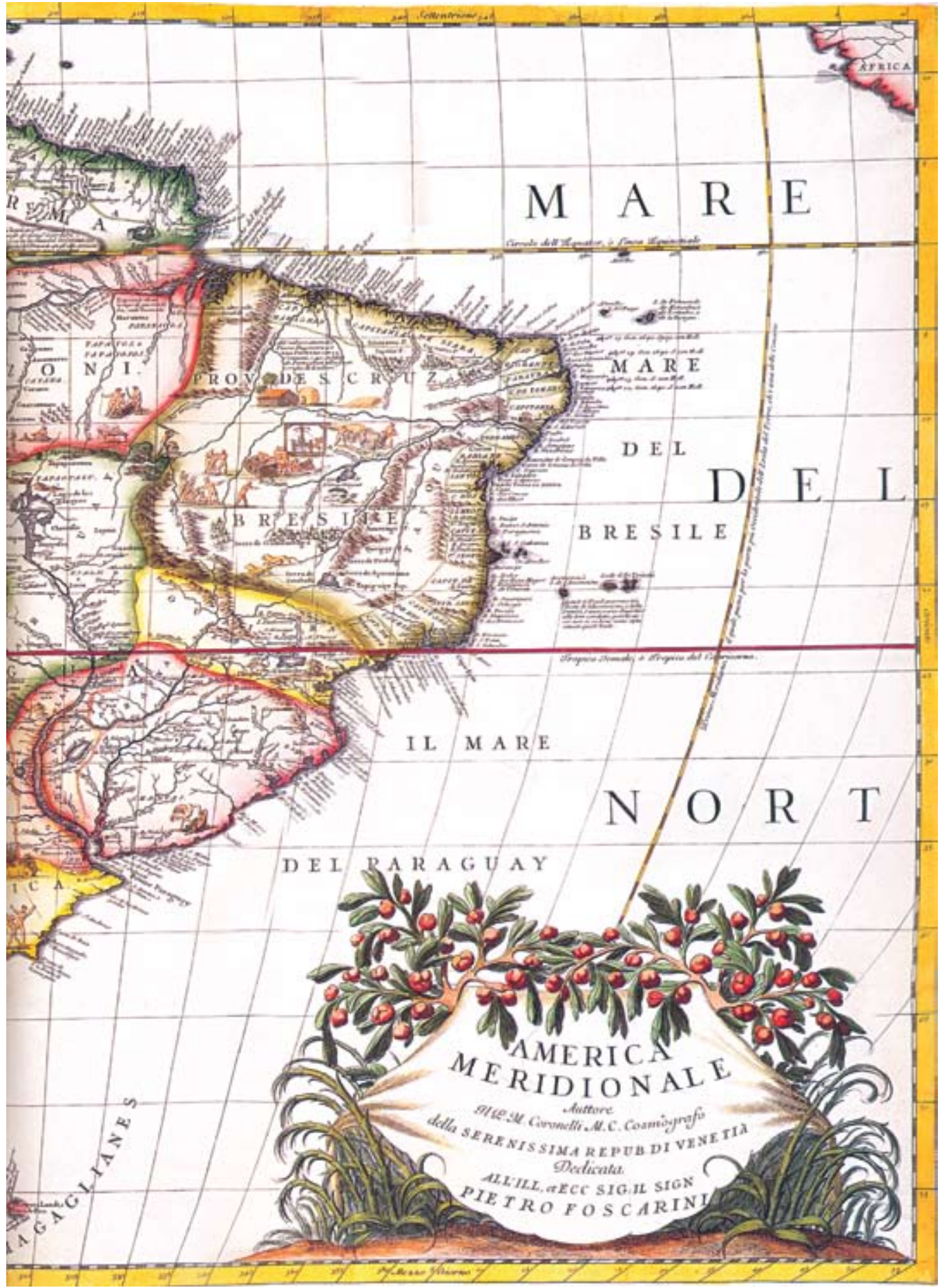

Figura 8 - "Mare del Bresile/ II Mare del Paraguay". Vicenzo Coronelli. América Meridionale. Veneza, 1692. Instituto de Estudos Brasileiros / USP lacervo depositado temporariamente pela Justiça Federall, São Paulo. 
26. Ver M. J. Guedes et al. (1990).

27. Ver Brotton (1997); e Craib (2000, p. 18).

28. L. F. Alencastro (2000, p. 105-116).
Dell'Arcano del Mare, publicado por Dudley, em 1646-1647, identificam-se, em torno da foz do Amazonas: II Mare di Guiana, II Mare di Amazones e II Mare di Brasilia.

Cartografia, geopolítica e ciclos econômicos

Ao longo do século XVI, o Atlântico constituiu-se como um espaço de comunicação que, mais do que separar, unia não tanto o "velho" ao "novo" mundo, mas também as duas partes de um mesmo mundo, o ocidente cristão. Deste modo, não parece obra do acaso que o Atlântico ficasse disposto, quase como um eixo, nos mapas mundo da época. Dito de outro modo, enquanto nos mapas manuscritos ibéricos cedo é delineado um oceano longitudinal entre a Europa e a América, que na maior parte das vezes não tem nome ou é apenas chamado genericamente Mar Oceano (e parece ser um antecedente do Atlântico); nos mapas europeus impressos, não ibéricos, dava-se-lhe a denominação de Oceano Meridional, um oceano transversal, diferente da seção situada ao norte do Equador, primeiro chamada Oceano Ocidental e, depois, mar do Norte.

A configuração longitudinal do Atlântico foi, por um lado, resultado das práticas de exploração e conquista das coroas portuguesa e espanhola, e da consequente articulação do "Mundo Atlântico" que esse impérios construíram de um e outro lado do oceano; e, por outro, em estreita relação com ele, também foi resultado da configuração geográfica longitudinal da América ${ }^{26}$. Não será demais recordar que esses mapas ibéricos, produzidos em consonância com a administração dos territórios ultramarinos, contribuíram mais do que quaisquer outros para a configuração de um Atlântico moderno, embora, devido ao caráter manuscrito - e, por tal razão, com uma circulação mais restrita -, o seu impacto no universo intelectual da época fosse lento, só se consolidando pelos finais do século XV.

Um século depois se estabelecia essa nova configuração da geografia da Terra: os mapas-múndi impressos mais difundidos, como o de Ortelius, de 1570, e de Mercator, de 1569 - cujos autores recorreram tanto aos clássicos como às informações mais atualizadas para criar sínteses que serviram de fontes a tantos outros cartógrafos, como Brought (1590) e Quad (1596) -, reproduziram e colocaram em circulação, para um público cada vez mais amplo, um esquema geográfico que terminaria impondo um "novo Ocidente" 27. É esse esquema gráfico que hoje nos surge tão familiar, onde o Atlântico deixa frente a frente, cara a cara, a Europa e a América.

Primeiro, a rede de rotas marítimas foi a base para as cartas náuticas manuscritas que figuravam o conjunto do oceano, onde se inscreviam os topônimos litorais e as ithas e arquipélagos, como pontos de encontro onde barcos e conhecimentos se cruzavam ${ }^{28}$. Mais tarde, os mapas impressos, segundo as suas escalas, correspondem a preocupações e idéias distintas, desde a ampla 
divulgação de roteiros marítimos, com as suas cartas exatas e detalhadas, às imagens de conjunto da metade sul do nosso Atlântico, em versão geopolítica, numa clara relação com os ciclos de exploração econômica: a madeira, o açúcar, a mineração, e, sempre, os escravos ${ }^{29}$. Para o tráfico negreiro existe mesmo um particular exemplo cartográfico, que não coincide com os mapas de grande escala, manuscritos e secretos: a Carta Reduzida da parte Meridional do Oceano Atlantico ou Occidental, de Jozé Fernandes Portugal, editada em Lisboa, em 1802, apresenta na base, em pormenor, os portos africanos, de saída, e brasileiros, de entrada de escravos. Um notável exemplo da ligação entre Cartografia e Poder.

No século XVIII, para o grande oceano, encontramos três denominações com igual importância, quase paralelas: a de mar do Norte, que se consolida em mapas de escalas continental e regional, desde os anos de 1630, e define-se por oposição ao Pacifico (mar do Sul); a de Oceano Meridional, que tem um segundo período de florescimento entre a produção dos cartógrafos franceses e ingleses, como Janvier, Belin, Bonne, Kitchin e Guthrie, desde meados de 1740; e a de Atlântico, que aparece desde os primeiros anos da centúria, e autonomiza-se como Ocean Atlantique Austral ou South Atlantic Ocean, nas obras de Reynolds e Arrowsmith ou Lapie e Lale, a partir do último quartel do século XVIIII3. Ao longo do século XIX, o Atlântico sul, sua denominação atual, vai fixar-se em definitivo.

Mais do que períodos em que predominaram certas designações, os múltiplos ensaios, as variações entre as escalas e a inquietante e permanente relação com o Pacífico, revelam a instabilidade que parece ter caracterizado o processo de construção do Atlântico moderno. A imagem do Atlântico formou-se e evoluiu graças a algumas das potências coloniais que organizaram os seus impérios em torno dele: primeiro Portugal e a Espanha, depois a Holanda, a França e a Inglaterra. Existem mapas emblemáticos para compreender como muda o olhar europeu sobre o Attântico sul e os seus territórios: o Mar di Aethiopia, de Jansonius, c. 1640, é o Império Holandês, como herança do português, durante a união das coroas ibéricas; a Carte réduite de l'Océan Meridional, de Bellin, de 1746, figura o desenvolvimento do colonialismo francês; os mapas do Almirantado Britânico sobre o South Atlantic Ocean, de meados do século XIX, serão testemunho de quem controla, também cartograficamente, os oceanos.

\section{REFERÊNCIAS}

ADONIAS, I. (Org.). Mapa: imagens da formação territorial brasileira. Rio de Janeiro: Odebrecht, 1993.

ALEGRIA, M. F. et al. Portuguese Cartography in the Renaissance. In: WOODWARD, D. (ed.). The History of the Cartography. Cartography in the European Renaissance, 3. Chicago: The University Chicago Press, 2007. p. 975-1068.
29. Ver V. M. Godinho (1981).

30. Ver J. Parry (1974) 
ALENCASTRO, L. F. de. O trato dos viventes: formação do Brasil no Atlântico sul, séculos XVI e XVII. São Paulo: Companhia das Letras, 2000.

APIANUS, P.; GIRAVA, J. La cosmographia de Pedro Apiano/ corregida y añadida por Gemma Frisio, medico y mathematico; La manera de descriuir y situar los Lugares, con el Vso del Anillo Astronómico, del mismo autor Gemma Frisio; El Sitio y Descripcion de las Indias y Mundo Nueuo, sacada de la Historia de Francisco Lopez de Gomara, y de la Cosmographia de Ieronymo Giraua Tarragonez. Anvers: Iuan Bellero, 1575.

BOXER, C. R. O Império marítimo português, 1415-1825. Lisboa: Edições 70, 1992.

BRAUDEL, F. El Mediterráneo y el mundo mediterráneo en la época de Felipe II (1949). México: Fondo de Cultura Econômica, 1992.

BRESC, H. M. In: LE GOFF, J.; SCHMITT, Jean-Claude (Orgs.). Diccionario razonado del Occidente medieval (1999). Madrid: Akal, 2003. p. 480-486.

CORBAIN, A.; RICHARD, H. El mar, terror y fascinación. Barcelona: Paidós, 2004.

CORTESÃO, A.; TEXEIRA DA MOTA, A. Portugaliae monumenta cartographica. 6 vols. Lisboa: Comissão das Comemorações do V Centenário da Morte do Infante D. Henrique, 1960-1962.

CORTESÃO, J. História do Brasil nos velbos mapas. Rio de Janeiro: Instituto Rio Branco do Ministério das Relações Exteriores, 1965 e 1971. 2 vols.

COSGROVE, D. Apollo's eye. A cartographic genealogy of the earth in Western imagination. Baltimore, The Johns Hopkins University Press, 2001.

EDNEY, M. H. Knowlege and Cartography in the Early Atlantic. In: CANNY, Nicholas; MORGAN, Philip D. Morgan (ed.). Oxford Handbook on the Atlantic World, c.1450-1820. Oxford: Oxford University Press, (no prelo).

GARCIA, J. C. (coord.) A Nova Lusitânia: imagens cartográficas do Brasil nas Colecções da Biblioteca Nacional. Lisboa: Comissão Nacional para as Comemorações dos Descobrimentos Portugueses, 2001.

GILLIS, J. Islands of the mind. How the human imagination created the Atlantic world. Hampshire: Palgrave MacMillan, 2004.

GODINHO, V. M. Os Descobrimentos e a economia mundial. Lisboa: Presença, 1981.

GUEDES, M. J. et al. (coord.). Portugal-Brasil: a era dos descobrimentos atlânticos. Lisboa: Bertrand, 1990.

JACOB, C. L'empire des cartes. Approche théorique de la cartographie à travers l'historie. Paris: Albin Michel, 1992.

LESTRINGANT, F. Iles. In: PELLETIER, M. (ed.). Géographie du monde au Moyen Age et à la Renaissance. Paris: Editions du Comité des Travaux Historiques et Scientifiques, 1989.

LEWIS, M. W. Dividing the ocean. The Geographical Review, New York, v. 89, n. 2, p. 188-214, abr. 1999. 
LOIS, C.; GARCIA, J. C. The South of Mare Oceanus: maps and geographical terms. In: INTERNACIONAL CONFERENCE ON THE HISTORY OF CARTOGRAPHY, 22, 2007, Berna. (mimeo).

LÓPEZ DE GÓMARA, Francisco. La bistoria de las Indias y la conquista de México. Medina del Campo, 1552.

MANCKE, E. Early modern expansion and the politicization of oceanic espace. The Geographical Review, New York, v. 89, n. 1, p. 225-236, jan. 1999.

MARTÍN-MERÁS, M. L. Las enseñanzas náuticas en la Casa de la Contratación de Sevilla. In: ACOSTA RODRÍGUEZ et al. La Casa de Contratación y la navegación entre España y las Indias. Sevilla: Universidad de Sevilla, Consejo Superior de Investigaciones Científicas y Fundación El Monte, 2003. p. 667-693.

MAURO, F. Portugal, o Brasil e o Atlântico, 1570-1670. Lisboa: Estampa, 1998.

PARRY, J. El descubrimiento del mar (1974). Barcelona: Crítica, 1989.

PÉREZ VILATELA, L. Los nombres del mar de más allá de las Columnas de Hércules en la Antigüedad. In: CONGRESO INTERNACIONAL EL ESTRECHO DE GIBRALTAR, 2, 1990, Ceuta. Actas..., 2. Madrid: Universidad Nacional de Educación a Distancia, 1995. p. 165-178.

PÉRON, F. Monstruos y Maravillas del Mar (2004). In: CORBAIN, A.; RICHARD, H. El mar, terror y fascinación. Barcelona: Paidós, 2005.

PETERSON, R. G., STRAMMA, L.; KORTUM, G. Early concepts and charts of ocean circulation. Progress in Oceanography, v. 37, n. 1, p. 1-115, 1996.

PIEPER, R. The Impact of the Atlantic on European Self-perception. European World-maps of the $16^{\text {th }}$ century". In: PIETSCHMANN, H. (Ed). Atlantic bistory. History of the Atlantic system 1580-1830. Göttingen: Vanderhoeck \& Ruprecht, 2002.

RANDLES, W. La représentation e l'Atlantique. Islenba, 4, p. 5-16, 1989.

RELAÑO, F. The shaping of Africa: cosmographic discourse and cartographic science in late medieval and early modern Europe. Ashgate: Aldershot, 2002.

RELAÑO, F. Cartography and Discoveries: the Re-definition of Ptolomaic Model in the First Quarter of the Sixteenth century. In: CURTO, D. R.; CATTANEO, A.; ALMEIDA, A. F. $L a$ cartografia europea tra primo Rinascimento e fine dell'Illuminismo. Florença: Leo S. Olschki, 2003. p.49-61.

RONCONI, A. Per l'onomastica antica dei mari. Studi Italiani di Filologia Classica, $n^{\circ}$ 9, p. 193-242 e 257-331, 1931.

STEINBERG, P. E. The social construction of the ocean. Cambridge: Cambridge University Press, 2001.

Artigo apresentado em 8/2008. Aprovado em 3/2009. 